treatment in British Columbia. But under the trade agreement, a party cannot seek better treatment in one jurisdiction because it is offered in another.

In a post on worldtradelaw.typepad .com, Grierson-Weiler expressed his concern that these types of cases attract too much attention: "Such stories don't just provide some modicum of credibility for manifestly incredulous legal claims; they reinforce commonly-held beliefs about the sacred quality of a method of socialised medicine that verge upon some sort of political existentialism."

Dr. Danielle Martin, chair of Canadian Doctors for Medicare, is not so quick to dismiss Howard's attack on Canada's health care system. With more and more private health care providers opening shop in Canada, pressure from US investors is inevitable, she says. "The threat is real. ... If it's not him, it will probably be someone else. Once the big guys come in, we'll have real problems."

Howard believes his case is strong because circumstances have changed since the trade agreement came into effect. "In 1994, the government maybe had a case that medicare was grandfathered in, but today, in 2008, the medicare program has eroded. There are private centres all around." He also claims many Canadian politicians encouraged his plans in private but distanced themselves from him in public. As well, Howard wants the issue of US investment in Canadian health care brought into the open.

"It involves much more than just making a profit. I want Canadians to have the best care, and they can't get that under the status quo. But mainly I'm doing this because I've had enough of the hypocrisy."

Even if he fails to get a penny from the Canadian government, Howard says he will continue to look for ways to invest in Canadian health care. "I'm not done with Canada. I know that I can bring a lot more in terms of health care services to Canada. I have family and friends there, and I'm not going to abandon them because the government can't decide who it wants to be." - Roger Collier, CMAJ

DOI: $10.1503 / \mathrm{cmaj} .081703$

\section{Federal election wrap: medical profession to be sparsely represented in House of Commons}

Published at www.cmaj.ca on Oct. 17, 2008

$\mathrm{I}$ f economics truly is "the dismal science," then voters might well be tempted to conclude that politics is the dismal art.

As Canadians trekked to the polls on Oct. 14 to make their choices in the 40th general election, pollsters warned that all those voters seemed singularly unimpressed with their options - party leaders were largely uninspiring; campaigns lacklustre and strategies mediocre, if not incoherent. All parties seemed resolutely determined to avoid issues like health care. In fact, it barely made a ripple in the political pond throughout the 5-week campaign despite being consistently rated as a major public concern.

Small wonder, then, that many eligible voters did not make the trek, resulting in a historic low turnout of $59 \%$ as Prime Minister Stephen Harper and the governing Conservatives garnered 143 seats and earned their second consecutive minority. The Liberals plummeted to 76. The Bloc Quebecois held at 50, while the New Democrats rose to 37. The Green Party was shut out, while 2 independents were elected.
Within that mix lies another harsh reality: the medical community will continue to be sparsely represented within Parliament.

There were 4 physicians in the House of Commons when it was dissolved. There will be 4 in the new Parliament - in fact, the same 4 stalwarts as in the previous one. All are Liberals and all are general practitioners:

- Dr. Carolyn Bennett (St. Paul's)

- Dr. Hedy Fry (Vancouver Centre)

- Dr. Keith Martin (Esquimalt Juan De Fuca)

- Dr. Bernard Patry (Pierrefonds Dollard).

It will be Bennett's fifth term in the House, while Martin, Fry and Patry have now successfully run 6 times.

Eleven other physicians who sought office saw their political aspirations scuttled:

- Dr. Pierre Gfeller, general practitioner, Liberal (Laurentides-Labelle)

- Dr. Qais Ghanem, neurophysiologist, Green Party (Ottawa South)

- Dr. Sean Godfrey, pediatrician, Liberal (Oshawa)

- Dr. Gordon Guyatt, professor, McMaster University Department of

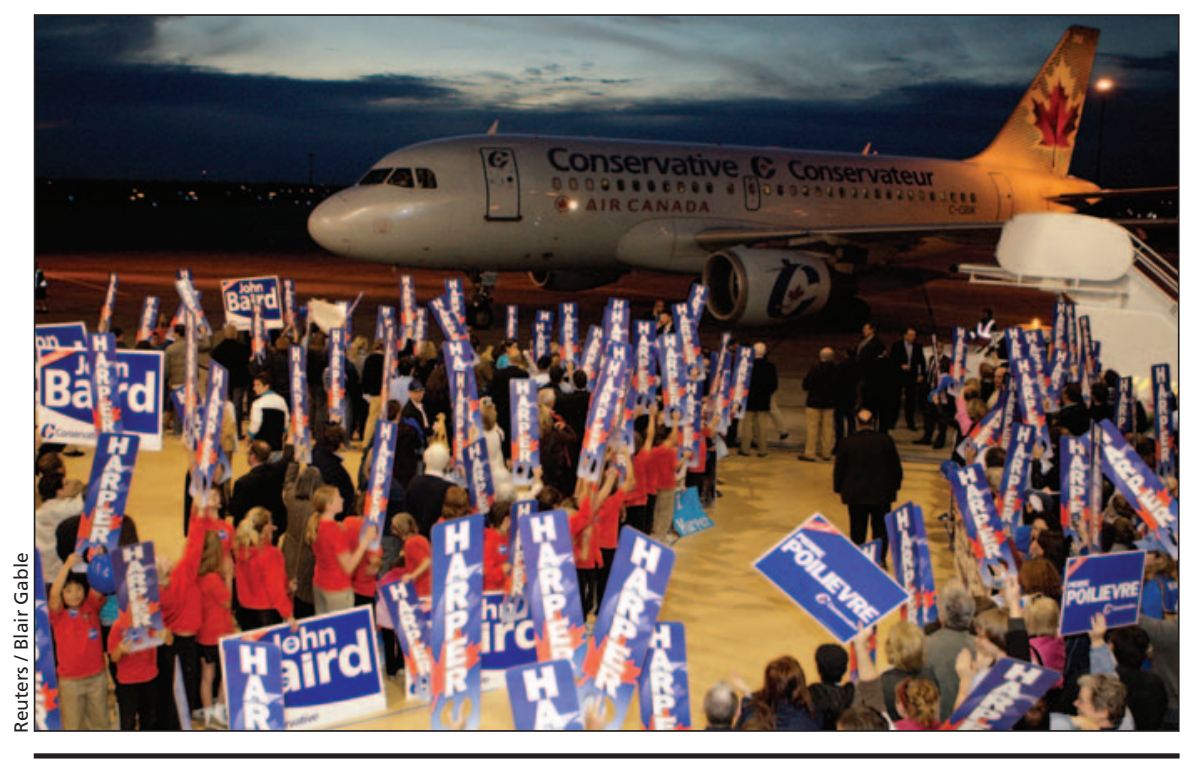

Re-elected Prime Minister Stephen Harper arrives at the Canada Reception Centre in Ottawa, Ontario, a day after his Conservatives captured their second consecutive minority. 
Clinical Epidemiology \& Biostatistics, New Democrat (Ancaster-Dundas-Flamborough-Westdale)

- Dr. Eric Hoskins, general medicine/ epidemiology, War Child Canada president, youngest ever recipient of United Nations Association in Canada's Lester B. Pearson Peace medal, Liberal (Haldimand-Norfolk)

- Dr. Benson Lau, family physician, Conservative (Scarborough Agincourt)

- Dr. Robert O'Connor, family physician, Green Party (Bonavista-Gander-Grand Falls-Windsor)

- Dr. André Sylvestre, family physician, Green Party (Pontiac)

- Dr. Lionel Traverse, pediatrician, Liberal (Abbotsford)

- Dr. Georgina Wilcock, chief of the Scarborough Hospital Department of Obstetrics and Gynecology, Green Party (Don Valley West)

- Dr. Martha Jo Willard, pathologist, Liberal (Brandon-Souris)

Faring even less favorably than physicians were nurses. Of 22 candidates with a nursing background, just one, Conservative Cathy McLeod (Kamloops-Thompson-Cariboo), the former mayor of Pemberton, British Columbia, prevailed.

As health professionals, physicians and nurses will lag well behind lawyers (50) in Parliamentary representation. They also trailed political aides (32), teachers (17), farmers (16), journalists (7) and restauranteurs (5) but matched policeman (4) and chiropractors (4).

The 4 chiropractors all served in the past Parliament:

- Colin Carrie, Conservative (Oshawa)

- Ruby Dhalla, Liberal (BramptonSpringdale)

- Gary Goodyear, Conservative (Cambridge)

- James Lunney, Conservative (Nanaimo-Alberni)

Dentist, Christian missionary and Conservative Harold Albrecht (Kitchener-Conestoga) was the only other health professional elected to Parliament.

But several other Members of Parliament do have at least a measure of experience in dealing with health issues. Re-elected were: Conservative Diane Finley (Haldimand-Norfolk), who helped establish the private ambulance services company Canadian Medical Response; New Democrat Peter Julian (Burnaby-New Westminster), executive director of the Western Institute for the Deaf and Hard of Hearing; New Democrat Brian Masse (Windsor West), a long-time activist for the disabled; and Bloc Quebecois Jean-Yves Laforest (Saint Maurice-Champlain), former psychomotor rehabilitation specialist at the Trois-Rivières Regional General Hospital.

Among newcomers to the House with a measure of health-related experience are: Liberal Kirsty Duncan (Etobicoke North), associate professor of health studies at the University of Toronto; and New Democrat Glenn Thibeault (Sudbury), a former manager of residential programs for the handicapped.

Almost as sparse as health profession representation in the House of Commons were actual health policy commitments made on the hustings, particularly from Harper's Conservatives, who essentially took no stance on 10 health issues during a CMAJ election survey (CMAJ 2008;179[8]:757-8).

Among the few commitments made by the Conservatives were modest measures to address the shortage of doctors and nurses, including:

- $\$ 10$ million per year over 4 years to fund 50 new residency spots in teaching hospitals

- A \$5 million fund to attract Canadian physicians practising abroad to return to Canada. The Conservatives projected the fund would result in the repatriation of 300 physicians over 4 years

- $\$ 5$ million over 3 years to "develop recruitment and retention strategies for the nursing profession."

Other Conservative commitments were extremely broad in nature. Harper's platform promises to "continue to take creative measures to tackle major lung, heart and neurological diseases." The new government also vows to end discriminatory life insurance practices and crackdown on tobacco advertising in print and electronic media reached by children. - Wayne Kondro, CMAJ

DOI:10.1503/cmaj.081688
FOR THE RECORD

\section{Apology measures}

\section{proliferate}

Canadian physicians seeking to improve the way they communicate with patients who've been harmed are getting plenty of assistance this year as provincial governments and national organizations unveil measures to promote accountability and transparency.

Ontario and Alberta will likely become the fourth and fifth provinces, respectively, to pass "apology acts" after introducing legislation in October.

And earlier this year, guidelines for disclosing harm to patients were released, separately, by the Canadian Patient Safety Institute and the Canadian Medical Protective Association.

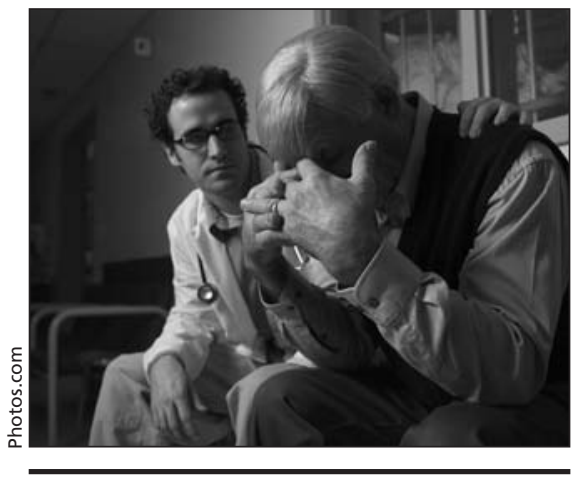

Apology legislation aims to promote "open and frank" discussion.

The guidelines and the provincial laws complement each other, since the intent of the latter is to "remove concerns about potential legal liability and other sanctions" when health professionals tell patients about harm, says Brent Windwick, chair of the Institute's legal and regulatory affairs advisory committee. He warns that apology legislation doesn't remove the need for effective and thorough training for health professionals about how to tell patients about adverse events, but it will "remove a significant source of hesitation" about speaking to patients who've suffered harm.

British Columbia was the first province to pass an apology act, in 2006, with Manitoba and Saskatchewan following suit in 2007. 